\title{
Pendekatan Saintifik dengan Metode Gasing pada Pembelajaran Fisika
}

\section{Yesi Purwari}

SMAN 3 Solok Selatan

Article Info:

Accepted : 18 Mei 2020

Published Online : 26 Mei 202

\begin{abstract}
Abtract
This study aims to determine the effect of the Scientific Approach to the Gasing Method in Physics Learning. The subjects in this study were students of class XII MIPA 3 SMAN 3 Solok Selatan. This type of research is classroom action research conducted through two cycles of implementation through four stages, namely planning, action, observation, and reflection. Data on learning outcomes of physics are collected through tests of learning outcomes and student learning activities are collected with an observation sheet. Data were analyzed quantitatively and qualitatively. The results showed that the average score of learning outcomes increased from 73.75 in cycle 1 to 80.31 in cycle 2 then the average score of student learning activities increased from 66.25 in cycle 1 to 86.25 in cycle 2. Results this research is expected to be used alternatively by physics teachers who want to improve the learning process in the classroom through a scientific approach with gasing method.
\end{abstract}

Keywords: Gasing Method, Scientific Approach, Physics Learning Outcomes

This is an open access article distributed under the Creative Commons Attribution License, which permits unrestricted use,
distribution, and reproduction in any medium, provided the original work is properly cited. 02020 by author

\section{PENDAHULUAN}

Pembelajaran fisika seharusnya menjadi pembelajaran yang menarik, karena fisika membahas tentang gejala-gejala alam yang dekat dengan lingkungan siswa sebagai pembelajar (Alpindo, 2014). Kemajuan dibidang teori pembelajaran seharusnya juga memberi dampak baik pada kelas pembelajaran fisika.Namun kelas pembelajaran fisika menunjukkan fakta berbeda, sebagian proses pembelajaran fisika yang dilakukan guru belum mampu membawa siswa untuk menyenanginya. Proses pembelajaran seolah tidak memperlihatkan hubungan antara fisika dan lingkungan alam di sekitar siswa (Sambada, 2012). Salah satu contoh kasus pembelajaran fisika yang peneliti temui adalah ketika permasalahan fisika yang diberikan kepada siswa berbeda dari contoh yang diberikan, siswa tidak mampu mengerjakannya tapi bila diberikan permasalahan yang mirip siswa baru dapat menyelesaikannya.

Dari data awal yang peneliti peroleh di kelas XII MIPA 3 sebagian besar siswa belum menguasai konsep listrik dinamis. Hal ini diketahui dari tes awal yang peneliti berikan dimana hanya ada 4 orang siswa yang memperoleh nilai diatas 75 sedangkan 28 siswa lainnya memperoleh nilai dibawah 75 . Perolehan hasil tes awal secara rata-rata juga masih sangat rendah yaitu 33. Jika di perhatikan dari persentase penguasaan konsep berdasarkan materi pokok secara keseluruhan persentase penguasaan konsep listrik masih sangat rendah, hal ini semakin memperkuat fakta bahwa masih banyak siswa yang belum menguasai konsep listrik dalam pembelajaran fisika (Gunawan, Harjono, \& Sutrio, 2017).

Rendahnya penguasaan konsep fisika siswa bisa disebabkan berbagai faktor seperti guru, sumber belajar yang digunakan maupun metode belajar yang diterapkan (Supardi, Leonard, Suhendri, \& Rismurdiyati, 2015) . Rendahnya penguasaan konsep siswa akan mengganggu efektifitas belajar serta mengganggu pemikiran siswa dalam menerima pengetahuan berikutnya, karena itu penguasaan konsep perlu dioptimalkan melalui pendekatan dan metode yang tepat agar siswa tidak mengalami kesulitan menerima materi berikutnya (Aprilia, 2015).

Berdasarkan permasalahan tersebut, peneliti tertarik untuk mencoba menerapkan Pendekatan Saintifik. Pemilihan pendekatan saintifik karena pendekatan ini cocok digunakan dalam pembelajaran fisika karena di 
dalamnya terdapat langkah-langkah ilmiah yang membuat proses pembelajaran lebih bermakna bagi siswa (Jaya, Patasik, Sembel, Subagiyo, \& Yunus, 2014). Disamping itu pendekatan saintifik merupakan salah satu pendekatan yang disarankan dalam implementasi kurikulum 2013.Untuk lebih berhasilnya pembelajaran yang akan dilakukan peneliti juga menggabungkan metode gasing kedalam pendekatan saintifik. Dalam metode gasing soal fisika diselesaikan dengan operasi matematika sederhana (Jatiutoro, Sunarno, \& Soeparmi, 2018). Metode ini dipilih karena beberapa siswa kelas XII yang mampu menyelesaikan soal fisika dengan rumus tidak mampu menjelaskan konsep yang terkandung dalam rumus fisika, bahkan beberapa siswa yang lainnya tidak mampu menerapkan rumus untuk menyelesaikan soal fisika.

Metode gasing adalah suatu metode pembelajaran fisika yang dikembangkan agar fisika dapat dipelajari dan diajarkan secara gampang, asyik dan menyenangkan (Faizah, 2012; Nurfathoanah, 2017). Metode Gasing mengajarkan bagaimana berfikir seperti seorang fisikawan dalam menyelesaikan soal-soal fisika dengan pendekatan logika berdasarkan konsep dasar fisika dengan lima tahapan : (1)Berimajinasi/ berfantasi, (2) Dialog sederhana,(3) Menyajikan contoh soal secara relevan, (4) Menyajikan materi secara mendalam, (5) Memberikan variasi soal (Surya, 2008).

Pembelajaran yang menerapkan pendekatan saintifik akan menyentuh tiga ranah yaitu : sikap (afektif), pengetahuan (kognitif), dan keterampilan (psikomotor) (Leksono, 2015b). Dengan proses pembelajaran yang demikian diharapkan hasil belajar akan melahirkan peserta didik yang produktif, kreatif, inovatif, dan afektif melalui penguatan sikap, pengetahuan dan keterampilan yang terintegrasi (Leksono, 2015a). Langkah-langkah pendekatan saintifik pada pembelajaran kurikulum 2013:

1. Mengamati (dengan indra) : membaca, mendengar, menyimak, melihat (tanpa atau dengan alat) untuk mengidentifikasi hal-hal yang ingin diketahui.

2. Menanya : mengajukan pertanyaan tentang hal-hal yang tidak dipahami dari apa yang siamati atau pertanyaan untuk mendapatkan informasi tambahan tentang apa yang diamati.

3. Mencoba/mengumpulkan data : melakukan eksperimen, membaca sumber lain dan buku teks, mengamati objek/kejadian/aktivitas, wawancara dengan nara sumber, mengeksplorasi, mencoba, berdiskusi, mendemonstrasikan, meniru bentuk/gerak, memodifikasi/mengembangkan

4. Mengasosiasikan/mengolah informasi : siswa mengolah informasi yang telah dikumpulkan baik terbatas dari hasil kegiatan mengumpulkan/eksperimen maupun hasil kegiatan mengamati dan kegiatan mengumpulkan informasi. Menganalisis data dalam bentuk membuat kategori, mengasosiasi atau menghubungkan fenomena/informasi yang terkait dalam rangka menemukan suatu pola dan meyimpulkan.

5. Mengkomunikasikan : siswa menyampaikan hasil pengamatan, kesimpulan berdasarkan hasil analisis secara lisan, tertulis, atau media lainnya. Menyajikan laporan dalam bentuk bagan, diagram, atau grafik. Menyusun laporan tertulis dan menyajikan laporan yang meliputi proses, hasil dan kesimpulan secara lisan.

6. Mencipta : siswa menginovasi, mencipta, mendesain model, rancangan, produk (karya) berdasarkan pengetahuan yang dipelajari.

Berdasarkan uraian konsep metode gasing dan pendekatan saintifik diatas tahapan belajar model pembelajaran pendekatan saintifik dengan metode gasing ditunjukkan tabel berikut :

Tabel 1. Pendekatan Saintifik dengan Metode Gasing

\begin{tabular}{|c|c|c|c|}
\hline Metode Gasing & $\begin{array}{l}\text { Pendekatan } \\
\text { Saintifik }\end{array}$ & $\begin{array}{l}\text { Pendekatan Saintifik } \\
\text { denganMetode } \\
\text { Gasing }\end{array}$ & Aktivitas \\
\hline $\begin{array}{l}\text { Berimajinasi/ } \\
\text { berfantasi }\end{array}$ & Mengamati & Mengamati fakta & $\begin{array}{l}\text { Siswa mengamati aplikasi } \\
\text { materi yang akan di bahas }\end{array}$ \\
\hline Dialog sederhana & Menanya & $\begin{array}{l}\text { Diskusi hasil } \\
\text { pengamatan }\end{array}$ & $\begin{array}{l}\text { Siswa mendiskusikan hasil } \\
\text { pengamatan }\end{array}$ \\
\hline $\begin{array}{l}\text { Menyajikan contoh } \\
\text { soal secara relevan }\end{array}$ & Mencoba & $\begin{array}{l}\text { Mencoba/latihan soal } \\
\text { sederhana }\end{array}$ & $\begin{array}{l}\text { Siswa mencoba } \\
\text { mengerjakan latihan } \\
\text { sederhana }\end{array}$ \\
\hline $\begin{array}{l}\text { Menyajikan materi } \\
\text { secara mendalam }\end{array}$ & Mengasosiasi & $\begin{array}{l}\text { Merumuskan Konsep } \\
\text { /menyimpulkan }\end{array}$ & $\begin{array}{l}\text { Siswa menyimpulkan } \\
\text { konsep dari hasil latihan }\end{array}$ \\
\hline $\begin{array}{l}\text { Memberikan variasi } \\
\text { soal }\end{array}$ & Komunikasi & $\begin{array}{l}\text { Latihan soal yang lebih } \\
\text { kompleks }\end{array}$ & $\begin{array}{l}\text { Siswa berlatih soal yang } \\
\text { lebih kompleks }\end{array}$ \\
\hline
\end{tabular}




\section{METODE}

Penelitian ini merupakan Penelitian Tindakan Kelas (PTK), Subjek dalam penelitian ini adalah siswa kelas XII MIPA 3 SMAN 3 Solok Selatan. Pemilihan kelas berdasarkan analisis pemahaman konsep fisika siswa kelas XII. MIPA 3 peneliti menemukan banyak sekali siswa yang belum menguasai konsep fisika. Penelitian dilaksanakan pada semester I tahun pelajaran 2019/2020. Dalam penelitian ini dilakukan dengan langkah-langkah yang dimulai dari siklus I dan II yang pelaksanaannya melalui 4 (empat) tahap yaitu : perencanaan, tindakan, observasi, dan refleksi. Data hasil belajar fisika dikumpulkan dengan tes hasil belajar dan kegiatan belajar siswa dikumpulkan dengan lembar observasi .Data yang diperoleh dalam penelitian dianalisa dengan menggunakan analisa data secara kualitatif dan kuantitatif dengan menelaah sejak pengumpulan data sampai seluruh data terku mpul. Data kuantitatif dianalisa dengan menghitung rata-rata tes hasil belajar menggunakan rumus rerata. Analisa data yang menggunakan teknik deskriptif kualitatif memanfaatkan persentase merupakan langkah awal saja dari keseluruhan proses analisis (Arikunto, 2009) . Analisis kualitatif harus dinyatakan dalam sebuah prediket yang menunjukkan ukuran kualitas. Adapun interval prediket dalam penelitian ini (1) Interval $81 \%$ - 100\%kategori sangat baik (2) Interval $61 \%$ - 80\%kategori baik, (3) Interval $41 \%$ - 60\%kategori cukup, (4) Interval 21\% - 40\%kategori kurang baik, (5) Interval $0-20 \%$ kategori tidak baik. Indikator keberhasilan proses pembelajaran adalah tercapainya nilai hasil belajar $80 \%$ siswa memperoleh nilai diatas KKM 75 dengan rumus persentase nilai hasil belajar siswa :

$$
\text { Persentase nilai hasil belajar }=\frac{\text { jumlah siswa tuntas }}{\text { jumlah seluruh siswa }} \times 100 \%
$$

\section{HASIL DAN PEMBAHASAN}

Data hasil belajar dan data pengamatan terhadap aktivitas belajar siswa pada siklus 1 dapat diperhatikan pada tabel berikut :

Tabel 2. Tingkat Pencapaian Hasil Belajar Siswa Siklus 1

\begin{tabular}{lcccc}
\hline No & Skor & Frekuensi & Persentase & Keterangan \\
\hline 1 & $41-50$ & 1 & $3,125 \%$ & \\
2 & $51-60$ & 5 & $15,625 \%$ & \\
3 & $61-70$ & 11 & $34,375 \%$ & \\
4 & $71-80$ & 11 & $34,375 \%$ & \\
5 & $81-90$ & 4 & $12,5 \%$ & \\
6 & $91-100$ & 75 & 75 & \\
& KKM & 50 & & \\
& Nilai terendah & 90 & $46,875 \%$ & \\
& Nilai Tertinggi & & & \\
& \% tuntas & 73,75 &
\end{tabular}

Data diatas menunjukkan masih banyak siswa kelas XII. MIPA 3 yang nilai hasil belajarnya dibawah KKM yaitu sebanyak 17 orang siswa.

Tabel 3. Aktifitas siswa Siklus 1

\begin{tabular}{llcc}
\hline No & Kegiatan & Jumlah siswa aktif & Persentase \\
\hline 1 & Mengamati & 32 & $100 \%$ \\
2 & Diskusi & 14 & $43,75 \%$ \\
3 & Mencoba & 22 & $68,75 \%$ \\
4 & Merumus konsep & 6 & $18,75 \%$ \\
5 & Latihan soal & 32 & $100 \%$ \\
\hline
\end{tabular}

Data pada tabel diatas memperlihatkan pada kegiatan mengamati dan latihan soal seluruh siswa aktif. Sedangkan untuk kegiatan diskusi dan merumuskan konsep keaktifan siswa masih dibawah 50\%.

Kendala dan masalah yang muncul dalam pelaksanaan pembelajaran untuk siklus I :

1. Siswa masih kurang aktif dalam diskusi.

2. Siswa masih belum terbiasa dalam pembelajaran pendekatan saintifik dengan metode gasing.

3. Siswa masih perlu bimbingan guru pada tahap perumusan konsep/menyimpulkan 
4. Beberapa latihan yang bersifat kompleks masih belum mampu di selesaikan siswa.

Data hasil belajar dan data pengamat an terhadap aktivitas belajar siswa pada siklus 2 dapat diperhatikan pada tabel berikut :

Tabel 4. Tingkat Pencapaian Hasil Belajar Siswa Siklus 2

\begin{tabular}{lcccc}
\hline No & Skor & Frekuensi & Persentase & Keterangan \\
\hline 1 & $41-50$ & 1 & $3,125 \%$ & \\
2 & $51-60$ & 1 & $3,125 \%$ & \\
3 & $61-70$ & 4 & $12,5 \%$ & \\
4 & $71-80$ & 17 & $53,125 \%$ & \\
5 & $81-90$ & 8 & $25 \%$ & \\
6 & $91-100$ & 1 & $3,125 \%$ & \\
& KKM & 75 & & \\
& Nilai terendah & 50 & & \\
& Nilai Tertinggi & 100 & & \\
& \% tuntas & & & \\
& rata-rata kelas & 80,3125 & & \\
\hline
\end{tabular}

data diatas menunjukkan hasil yang semakin baik jika dibandingkan siklus I. Siswa kelas XII. MIPA 3 yang nilai hasil belajarnya dibawah KKM hanya 6 orang siswa.

Tabel 5. Aktifitas siswa Siklus 2

\begin{tabular}{llcc}
\hline No & Aktifitas & Jumlah siswa aktif & Persentase \\
\hline 1 & Mengamati & 32 & $100 \%$ \\
2 & Diskusi & 26 & $81,25 \%$ \\
3 & Mencoba & 32 & $100 \%$ \\
4 & Merumus konsep & 16 & $50 \%$ \\
5 & Latihan soal & 32 & $100 \%$ \\
\hline
\end{tabular}

Data pada tabel diatas memperlihatkan pada kegiatan mengamati, mencoba dan latihan soal seluruh siswa aktif. Pada kegiatan diskusi sebagian besar siswa sudah aktif meskipun belum secara keseluruhan. Sedangkan untuk kegiatan merumuskan konsep hanya separuh siswa yang aktif. Meskipun hanya separuh siswa yang aktif namun secara keseluruhan pembelajaran sudah menunjukkan perubahan ke arah yang lebih baik.

Pada siklus I masih terdapat 17 orang siswa yang nilainya berada di bawah KKM namun bila dilihat dari peningkatan hasil belajarnya secara rata-rata meningkat signifikan. Meningkatnya hasil belajar siswa disebabkan pengaruh metode gasing yang berperan menanamkan konsep fisika dengan meminimalkan penggunaan rumus. Siswa diminta menyelesaikan soal dengan menuliskan makna dari setiap angka yang dituliskan, sehingga siswa lebih memahami konsep yang terkandung dari setiap angka yang diberikan.

Tahapan yang ada dalam pendekatan saintifik dengan metode gasing juga berperan besar dalam peningkatan hasil belajar, karena masing-masing tahapan memiliki kontribusi dalam peningkatan pemahaman siswa (Astawan \& Mustika, 2013). Tahap mengamati fakta bertujuan agar siswa mengetahui aplikasi/penerapan konsep yang akan mereka pelajari sehingga siswa termotivasi untuk belajar. Tahap mengamati ini juga merupakan tahap awal agar tahap berikutnya dapat ikuti siswa dengan baik.

Tahap kedua yaitu diskusi/tanya jawab. Pada tahap ini siswa mendiskusikan fakta yang telah mereka amati dan mengajukan pertanyaan-pertanyaan yang berhubungan dengan fakta yang telah ditunjukkan. Pada tahap ketiga siswa mencoba beberapa latihan sederhana yang bertujuan agar siswa mampu memahami konsep sederhana dan kemudian mampu merumuskan konsep pada tahapan berikutnya. Tahap keempat adalah menyimpulkan/merumuskan konsep, Pada tahap ini siswa menyusun konsep berdasarkan hasil latihan soal sederhana dan buku sumber yang relevan. Pada tahap ini guru bertugas membimbing siswa agar konsepyang diperoleh siswa tidak melenceng dari konsep fisika yang seharusnya. Tahap kelima adalah latihan soal yang lebih kompleks. Pada tahapan ini siswa menyelesaikan soal-soal dengan tingkat kesulitan yang lebih tinggi. Tahapan ini juga berfungsi sebagai tahap pemberian tantangan bagi siswa sehingga di harapkan mereka terbiasa untuk menyelesaikan soal-soal yang lebih kompleks.

Meskipun secara umum aktifitas siswa sudah meningkat namun yang menjadi fokus peneliti ada pada tahap diskusi dan merumuskan konsep. Kedua tahapan ini menekankan pada kegiatan mengemukakan ide, 
pertanyaan atau gagasan. Siswa yang tidak terbiasa dan belum terlatih untuk mengemukakan ide terlihat pasif dan tidak aktif dalam kedua tahap pembelajaran tersebut. Hal ini menjadi tantangan bagi peneliti untuk meningkatkan aktifitas siswa pada siklus berikutnya.

Pada siklus II, meningkatnya hasil belajar siswa dipengaruhi siswa sudah mulai terbiasa dengan pendekatan saintifik dan metode gasing. Sebagian besar siswa sudah mulai aktif pada semua tahapan pembelajaran meskipun pada tahap perumusan konsep hanya 16 siswa yang aktif merumuskan konsep. Kendala yang peneliti temui di siklus I tidak lagi ditemukan pada siklus kedua. Atas dasar inilah peneliti memutuskan menghentikan kegiatan penelitian pada siklus ke dua.

Berhasilnya penelitian ini tidak terlepas dari kelebihan yang terdapat pada metode gasing dan pendekatan saintifik (Irawan, 2015). Berdasarkan temuan pada proses pembelajaran peneliti menemukan beberapa kelebihan dalam pembelajaran Pendekatan Saintifik dengan Metode Gasing

1. Siswa mengetahui dimana penerapan konsep fisika yang mereka pelajari.

2. Siswa tidak terpaku pada rumus fisika saja dalam penyelesaian soal karena dalam metode gasing siswa dilatih untuk menggunakan pemahaman terhadap besaran fisika dan menggunakan operasi matematika sederhana.

3. Siswa mampu menyelesaikan berbagai jenis soal mulai dari yang sederhana hingga yang kompleks

4. Siswa terlatih untuk menemukan sendiri rumusan konsep berdasarkan beberapa soal latihan sederhana

Meskipun banyak kelebihan pada pendekatan saintifik dengan metode gasing namun model pembelajaran ini tidak lepas dari beberapa kelemahan, diantaranya :

1. Pembelajaran ini memerlukan waktu yang banyak untuk melatih siswa dengan beragam soal fisika mulai yang sederhana hingga yang kompleks.

2. Pembelajaran ini memerlukan persiapan yang matang agar waktu pembelajaran lebih efisien.

3. Tidak semua materi fisika cocok dengan pembelajaran pendekatan saintifik dengan metode gasing.

\section{KESIMPULAN}

Berdasarkan hasil penelitian terdapat beberapa hal yang ditemukan dalam penelitian ini yaitu : (1). Pendekatan Saintifik dengan Metode Gasing dapat meningkatkan hasil dan aktivitas belajar fisika siswa kelas XII. MIPA 3 di SMAN 3 Solok Selatan. (2). Peningkatan rata-rata hasil belajar siswa secara klasikal pada siklus 1 sebesar 73,75 dan peningkatan rata-rata hasil belajar siswa secara klasikal pada siklus 2 sebesar 80,31. (3). Peningkatan rata-rata aktivitas belajar siswa secara klasikal pada siklus 1 sebesar 66,25 dan peningkatan rata-rata aktivitas belajar siswa secara klasikal pada siklus 2 sebesar 86,25.Pendekatan saintifik dengan metode gasing mampu meningkatkan hasil belajar dan aktivitas belajar siswa secara signifikan. Pendekatan saintifik dengan metode gasing dapat dijadikan salah satu model pembelajaran dalam mata pelajaran fisika. Meskipun pembelajaran ini membutuhkan persiapan matang oleh guru, namun dampak pembelajaran yang di hasilkan lebih berarti dan jauh lebih baik dari pembelajaran konvensional. Berdasarkan hasil penelitian ini peneliti menyarankan Pembelajaran yang meggunakan pendekatan saintifik dengan metode gasing dapat dijadikan alternatif oleh guru fisika yang ingin memperbaiki proses pembelajaran di kelas. Kemudian diharapkan pada peneliti selanjutnya untuk melakukan penelitian pada konsep/materi fisika lain sehingga dapat diketahui pada konsep apa saja metode ini memberikan efek positif terhadap pembelajaran

\section{DAFTAR RUJUKAN}

Alpindo, O. (2014). Pengaruh Pemberian Pertanyaan Higher Order Thinking Skill (HOTS) dalam Model Pembelajaran Problem Based Learning terhadap Hasil Belajar Fisika Siswa Kelas XI SMAN 2 Padang. PILLAR OF PHYSICS EDUCATION, 3(1).

Aprilia, L. (2015). Penerapan Perangkat Pembelajaran Materi Kalor melalui Pendekatan Saintifik dengan Model Pembelajaran Guided Discovery Kelas X SMAA. Inovasi Pendidikan Fisika, 3(3).

Arikunto, S. (2009). Dasar-dasar Evaluasi Pendidikan (edisi revisi).

Astawan, I. G., \& Mustika, I. W. (2013). Meningkatkan Aktivitas dan Kemampuan Memecahkan Masalah melalui Pembela-jaran Kuantum Teknik Fisika Gasing. Jurnal Pendidikan dan Pengajaran, 46(2 Juli).

Faizah, S. R. (2012). Efektivitas Penggunaan Strategi Pembelajaran Gasing (Gampang, Asyik, Dan Menyenangkan) Terhadap Hasil Belajar Peserta Didik Man 1 Purwodadi Pada Mata Pelajaran Fisika Kelas X Materi Pokok Gerak. IAIN Walisongo.

Gunawan, G., Harjono, A., \& Sutrio, S. (2017). Multimedia Interaktif dalam Pembelajaran Konsep Listrik bagi Calon Guru. Jurnal Pendidikan Fisika dan Teknologi, 1(1), 9-14. 
Irawan, N. W. (2015). Metode Gasing dengan Eksperimen untuk Meningkatan Hasil Belajar Fisika Konsep Mekanik Zat (Hukum Hooke) pada Peserta Didik Kelas X Multimedia Smk Negeri 2 Pati Semester Genap Tahun Ajaran 2014/2015. Paper presented at the Prosiding SNPS (Seminar Nasional Pendidikan Sains).

Jatiutoro, P., Sunarno, W., \& Soeparmi, S. (2018). Pembelajaran IPA Fisika dengan Model Problem Solving Menggunakan Metode Inkuiri Terbimbing dan Metode GASING Ditinjau dari Kemampuan Verbal dan Kemampuan Logika Matematika Siswa. INKUIRI: Jurnal Pendidikan IPA, 7(1), 133-142.

Jaya, G. W., Patasik, B., Sembel, E. K., Subagiyo, L., \& Yunus, M. (2014). Penerapan pendekatan saintifik melalui metode eksperimen pada pembelajaran fisika siswa kelas X MIA 3 SMA Negeri 1 Tenggarong (materi suhu dan kalor). Saintifika, 16(2).

Leksono, J. W. (2015a). Pendekatan Saintifik. proceedingfptk, 437.

Leksono, J. W. (2015b). Pendekatan Saintifik pada Kurikulum 2013 untuk Meningkatkan Keterampilan Berpikir Kritis Siswa. proceedingfptk, 437.

Nurfathoanah, N. (2017). Implementasi Metode Pembelajaran GASING (Gampang, Asyik dan Menyenangkan) Terhadap Hasil Belajar Fisika Peserta Didik Kelas X SMA Negeri 3 Polongbangkeng Utara. Jurnal Pendidikan Fisika, 5(3), 351-361.

Sambada, D. (2012). Peranan kreativitas siswa terhadap kemampuan memecahkan masalah fisika dalam pembelajaran kontekstual. Jurnal Penelitian Fisika dan Aplikasinya (JPFA), 2(2), 37-47.

Supardi, S. U., Leonard, L., Suhendri, H., \& Rismurdiyati, R. (2015). Pengaruh media pembelajaran dan minat belajar terhadap hasil belajar fisika. Formatif: Jurnal Ilmiah Pendidikan MIPA, 2(1).

Surya, Y. (2008). Fisika Gasing: Gampang, Asyik \& Menyenangkan: Jakarta: Surya Institute. 